\title{
State Open Universities (SOUs) in India: An Evaluation
} (A Case of Pt. Sundarlal Sharma Open University) Niradhar Dey

Project Director (ICSSR Funded Project), Associate Professor, School of Education, IGNOU, New Delhi, India Corresponding author: niradhar@ignou.ac.in

Received: 19 Sept., 2021

Revised: 24 Nov., 2021

Accepted: 11 Dec., 2021

\begin{abstract}
The paper seeks to evaluate the functioning of Pt. Sundarlal Sharma Open University, Bilaspur. The study is a part of an ICSSR sponsored project, "State Open Universities (SOUs) in India: An Evaluation”. Descriptive survey method has been used to conduct the study. Including the TOP University administrators, six programme coordinators; four regional directors; 30 study centre coordinators; 51 academic counselors; and 122 learners have been selected purposively as sample of the study. The tools like: Institutional profile for the University and the SCs; interview schedules for the Vice-chancellor, programme coordinators, director of the RCs, coordinators of the SCs, and academic counselors; and questionnaire for the learners have been developed for collecting data. The data have been analysed by using simple statistics like frequencies, percentage, and average scores. The results of the study emphasized that though there is definite growth in learner's enrollment and revenue generation, the other aspect of providing quality education should not be neglected. The newly established University has completed its ten years, still it needs to understand the concept of distance learning; its philosophy; the organization of the Open University and its functioning at different levels; empowering the faculties, academic counselors, as well as the SCs; theories and models of development of materials (print and electronic); and providing support services to the learners. For this, a large scale interaction is needed with the established system of distance learning like IGNOU. Ultimately, care should be taken to 'reach the unreached' which is the slogan of distance education system and the social responsibility of the University should be realized.
\end{abstract}

Keywords: SOUs, SCs, IGNOU, Vice-chancellor, distance education system

How to cite this article: Dey, N. (2021). State Open Universities (SOUs) in India: An Evaluation. Learning Community, 12(02): 127-146. 


\section{The Background}

"State Open Universities (SOUs) in India: An Evaluation", is a research project, sponsored by ICSSR, New Delhi. The broad aim of the project is to evaluate the overall functioning of three newly established State Open Universities in India. Currently, 15 Open Universities are functioning in India. Among them, one is National Open University i.e. Indira Gandhi National Open University, New Delhi, and other 14 are the State Open Universities established in different States.In the project, three Open Universities have been selected by Judgmental sampling technique keeping the criterion of recently established. Three Universities such as: Pt. Sundarlal Sharma Open University, Bilaspur, C.G. (Established in 2005); Utarakhand Open University, Nainital, U.K. (Established in 2005); and Krishna Kanta Handiqui State Open University, Guwahati, Assam, (Established in 2006), have been selected for the study. Field work for the study has been planned in three phases. The first phase of field work has been conducted during Sept. - Oct. 2015, in Pt. Sundarlal Sharma Open University, Bilaspur, C.G.

Second and third phases of field work will likely to be carried out in Utarakhand Open University, Nainital, and Krishna Kanta Handiqui State Open University, Guwahati, Assam. The field work data of the first phase of the project has been analysed. This is the initial analysis of the data. Final report will be prepared after completion of field work of all the phases of the study. The initial analysis of the first phase data has been reported in this paper.

\section{Review of Related Literature}

A number of in-depth evaluation and other studies have been conducted since the origin of distance education. In this study, the researches which have been conducted in last two decades have been reviewed for setting a base for the present study.

Panda \& Garg, (2003) pointed out in their study that much confusion prevails in universities when one moves from distance education to distance training or combines the two. They also highlighted that a significant challenge is to maintain a judicious balance between the distance education and distance training in the theory, practice and research. In holistic planning of distance education institutions, the important points are raised by research like; controversy, threat from the industrial houses, entering of private enterprises to education, internal faculty/staff strength and ignorance of willingness, significant flexibility for consideration of alternatives (Panda 2009, Haughey, 2003). Many important studies related to faculty workload, tenure, Promotion and incentives in distance education system have conducted by Berg (2000), Dougherty and Funke (1998), Pajo and Wallace (2001), Wolcott (1997), Wolcott and Betts (1999), and Panda (2003). The result of the study revealed that distance teaching is still considered as outreach in many American Universities, takes more time for planning and teaching, controversy over assigning credit to individual or to faculty, question of ownership, increase of salary, improvement of working condition and increasing faculty interest in making more contribution to distance learning.

Regarding the growth of Distance Education, Policy, Planning and Management in India, a number of studies have been conducted by Datt (1976), Anand (1979), Balsubramaniam (1986), Biswal (1979), Datt 
(1984 \& 1988), Khan (1982), Nagaraju (1982), Pugazhenthi (1985), Rao (1980), Sahoo (1985 \& 1989), Satpathy (1989). All most all the studies highlighted the gradual growth of Distance Education in India as a mere extension of the system of regular courses offered through traditional universities. Therefore the courses have had limitations in meeting the academic and the socio economic needs of distance students. Differences were witnessed with regard to administrative staff patterns and enrolment rate was found to be higher in Arts, Commerce and Education than in other disciplines. Mishra (1991) found that majority of distance education institutes in the universities had no autonomy, innovativeness and decision making power. Prasad (1987) pointed out the need for open education system so that educational opportunities can be extended to a broad cross-section of people. Singh et al. (1994) recommended revamping and upgrading correspondence courses into the distance education mode. Many studies have been conducted in SOUs about the system of student support services and the major highlighted points were; student support services must transcend teacher-student interaction called counseling, personal contact programme, tutoring, synchronous learning, mentoring etc. and incorporate elements of activities ranging from the announcement for admission to certification and post-certification and all other activities in between (Sewart 1978, Murgatoyd 1980, Koul and Kanwar 2006).

Dass and Dass (2001) and Sahoo \& Mucchal (2001), studied the instructional process and the role of information technology in distance education and found that the role of media has been considered important in distance education and the strategy involving printed lesson, video and discussion was effective. In a study by Venkaiah (2005), revealed that teleconferencing is widely used by Dr. B.R. Ambedkar Open University to supplement the learning process. Indira Gandhi National Open University placed a pioneer position so far as Open and Distance Education is concerned. Many researches have been conducted in IGNOU both at national and international levels which is strengthening the system of Distance Education.

\section{Operational Definitions of the Terms Used}

Three important terms have been used in this study which needs to be defined operationally.

Open University: Open University means the Universities which have established by the Act of a Government (Central or State) in India and have properly inspected and affiliated by National Regulatory bodies of Distance Education and/or University Grants Commission. It develops and runs the academic programmes at Certificate, Diploma, Bachelor, Master, and Research level in Open and Distance Learning mode.

State Open Universities in India: Presently, 14 State Open Universities have been established in India in different States. The functional jurisdictions of the Universities are within the geographical jurisdiction of that State. In the present study, Pt. Sundarlal Sharma Open University has been selected for study.

Evaluation Study: Institutional evaluation is a part of survey research. It involves detail survey of the institute such as: qualitative and quantitative indicators of standards and functioning. It 
covers the status and management of material and human resources of the institutes; Developing and transacting academic programmes; cost benefit aspects of the institute; and proper analyses of all the stakeholders involved in the system. The present study focuses the overall assessment of the functioning the University.

\section{Objectives of the Study}

The study has conducted by studying the objectives as follows:

1. To study the facilities available (material and human) in Pt. S.S. Open University.

2. To study the facilities available (material and human) in the Study Centres of the University.

3. To study the learners enrolment, drop outs and pass out percentage.

4. To study the process followed for developing academic programmes and transacting the curriculum.

5. To study the student support services provided by the University.

6. To study opinions of the learners and the academic counselors for improving support services of the learners and empowering the counselors.

7. To study the supervision and monitoring activities conducted by the University.

8. To study the admission criteria and management of various professional programmes.

9. To study the methods and media adopted in curriculum transaction by the University.

10. To study the management of delivering research degree programmes.

11. To study the cost benefits analysis of the University.

\section{Research Design}

Research Methodology: Hence it is an institutional evaluation study, descriptive survey method has been used to conduct the study.

Population of the Study: Pt. Sundarlal Sharma Open University, Bilaspur, C.G., and all its Regional Cetres, and Study Centres established across the State of Chhattisgarh are the population of this study. Particularly, the Vice-chancellor of the University, Programme Coordinators, Head of different sections of the University, Directors of the Regional Centres, Coordinators of the Study Centres, Academic Counsellors, and Learners in different programmes have been included in the study.

Sample of the Study: The following units of the population have been selected purposively which constitute sample of the study: 


\begin{tabular}{lllllll}
\hline \multirow{2}{*}{$\begin{array}{l}\text { Sl. } \\
\text { No. }\end{array}$} & Sample & Initial & \multicolumn{2}{c}{ Final Sample } & \multirow{2}{*}{ Total } & \multirow{2}{*}{$\begin{array}{l}\text { Technique of } \\
\text { Selection }\end{array}$} \\
& & Sample & Male & Female & & \\
01 & Vice-Chancellor & 01 & 01 & & 01 & - \\
03 & Programme Coordinators & 20 & 04 & 02 & 06 & Purposive \\
04 & RC Directors & 05 & 04 & - & 04 & Purposive \\
05 & Study Centres & 60 & - & & 30 & Purposive \\
06 & Study Centre Coordinators & 60 & 22 & 08 & 30 & Purposive \\
07 & Academic Counselors & 150 & 26 & 25 & 51 & Purposive \\
\hline
\end{tabular}

Tools and Techniques Used: The following tools have been developed for data collection:

1. Profile of State Open University.

2. Profile of the Study Centres.

3. Interview schedule for the Vice-Chancellor.

4. Interview schedule for the Programme Coordinators.

5. Interview schedule for the Directors of the Regional Centres.

6. Interview schedule for the Coordinators of the Study Centres.

7. Interview schedule for the Academic Counsellors.

8. Questionnaire for the Learners.

The above tools are self-made, prepared by the project coordinator as well as the research assistant. After writing the items of the tools, the content validity has been determined by the experts of the field. More than 10 experts in different fields have been consulted to finalize the tools. Before making it final it was tried out with a small group of subjects. The language and other technical errors have been minimized by trying out (initial administration) the tools.

Data Collection: The project coordinator had taken the formal permission from the Vicechancellor of the University for collection of data. The data were collected during the Month of September and October, 2015. The project director and the research assistant of the project visited the University, its Regional Centres, and the Study Centres. As per the sample, the subjects were either interviewed or requested for filling the questionnaire. The profile of the Open University and the Study Centres were filled by the researchers with the help of the officers concerned in the University and the Study Centres.

Data Analysis and Interpretation: As per the objectives of the study, the data have been organized demographically. Both quantitative and qualitative modes of analysis have been used to characterize the data. Simple descriptive statistics like the Frequencies, Percentage, and 
Average Scores have been used for analyzing the data as per the requirements. The data have been presented in tabular, figural, and with proper description. On the basis of the analysis of the data, results of the study have been reported.

\section{Analysis and Interpretation}

The data have been organized and analysed in seven different aspects of the study. Each aspect focuses the objective(s) stated above. The major aspects of the study analysed here are: availability of facilities (infrastructure and human resources) at the University main campus and Study Centres; status of Academic Programmes, enrollments, and pass out; admission criteria in different programmes; development of Academic Programmes and curriculum transaction; support services received and difficulties faced by the Academic Counsellors and the Learners; managing research degree programmes; and cost benefit analysis of the University.

\section{Availability of Facilities (infrastructure and human resources)}

\section{Material Resources}

Pt. Sundarlal Sharma Open University has established in the outer area of Bilaspur, Chhattisgarh, located in Birkona Village. It was established in the Year, 2005 by the Government of Chattisgarh. The total area of the University covers around 75 Acers of land. The construction of the first wing of the University has been completed and in functional condition where as the second wing was under construction. It was observed that the following infrastructural facilities were available in the University main campus and the Study Centers:

Table 1: Infrastructure at the University Main Campus and Study Centers

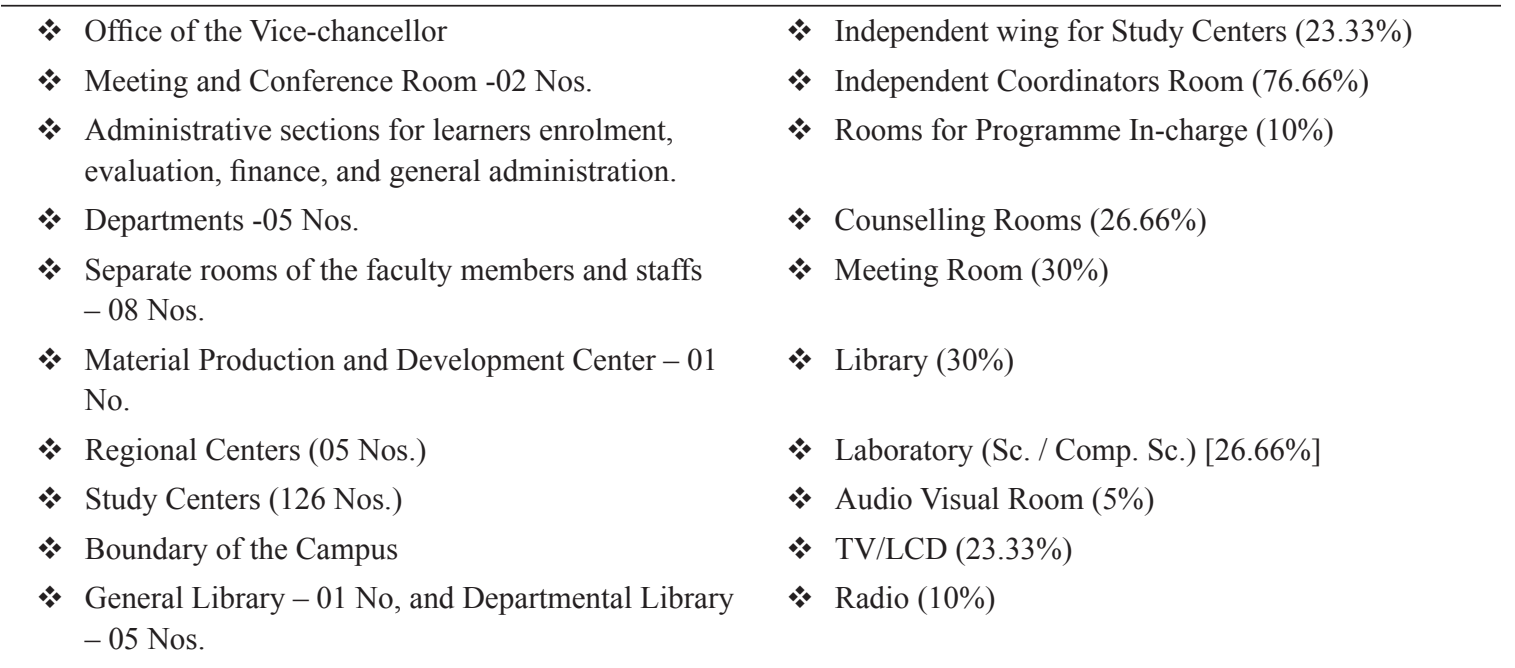


* Laboratory - 01 (Computer Science)

* Buses - 02 Nos. and Small Vehicles (10 Nos.)

* Roads inside the campus
Telephone $(33.33 \%)$

* Store Room (33.33\%)

* Computer $(23.33 \%)$

* Internet facility $(20 \%)$

* LCD Projector $(20 \%)$

* Toilet for Boys/Girls (66.66\%)

It was observed that the above infrastructures (Table 1) in University main campus were in good condition for use. Apart from the Main Campus of the University, it has five Regional Centers and 126 Study Centers established in different regions of the State of Chhattisgarh. The shortcomings what has observed, that there were shortage of audio-visual laboratory, laboratory for science and media production center. Low frequency radio centre should be established for providing timely interactive radio counseling to the learners. At the study centers, the necessary infrastructures were available on an around 30 percent of the SCs (the exact figure is presented in Table 1). The other study centers were running with scarcity of necessary physical facilities. It is important to note that 10 percent of study centers had established in non-educational institutes like Panchayat or Tahasil office campus. The Vice-chancellor of the University was very much keen to shift that study centers to near by educational institutions.

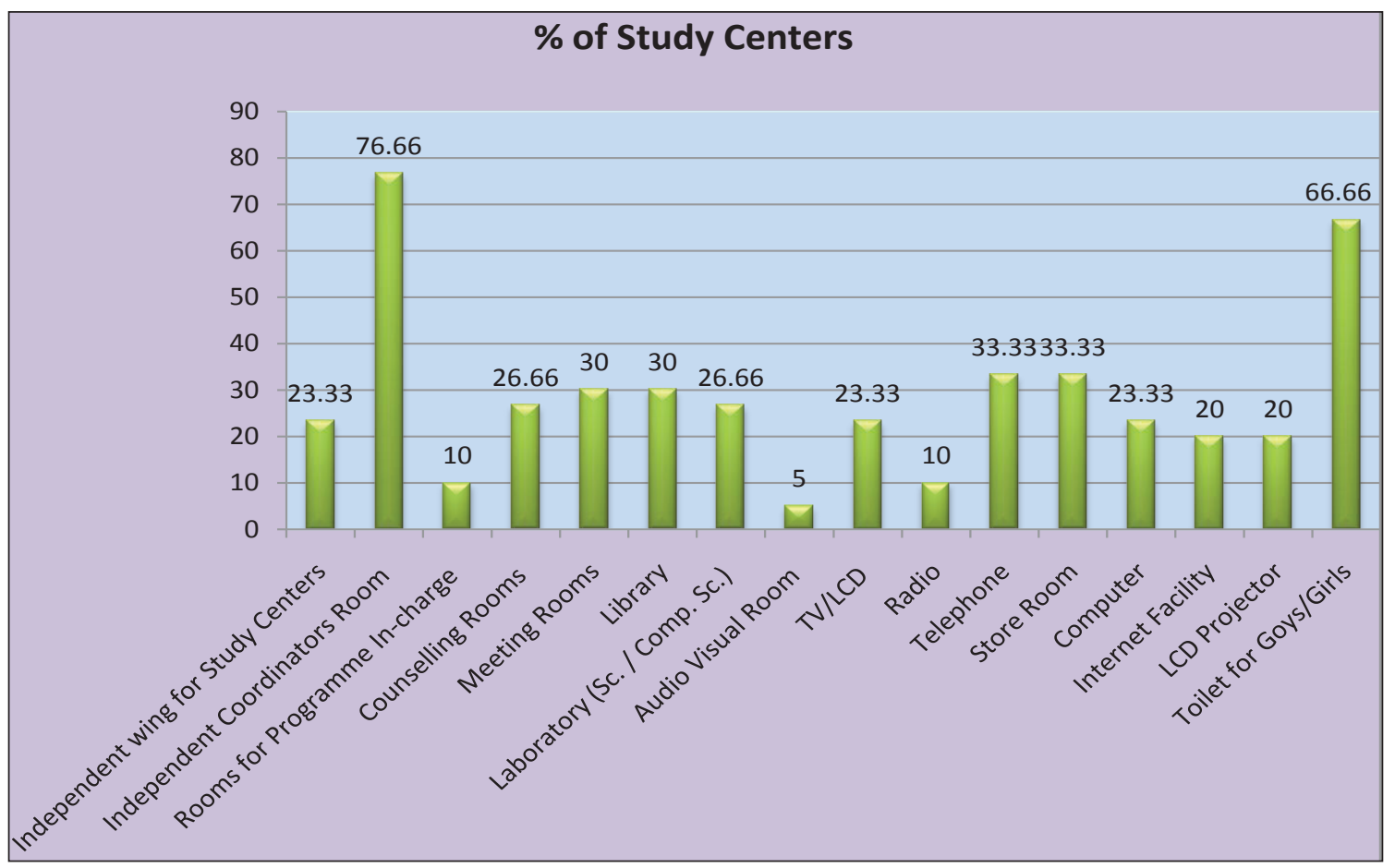

Fig. 1: Physical facilities in the Study Centers 
CP Dey

\section{Human Resources}

The following human resources were available in the main campus and the Study Centers.

Table 2: Human Resources at University main campus and Study Centers

\begin{tabular}{ll}
\hline University Main Campus & Study Centers \\
\hline Vice-chancellor & $*$ Programme In-charges (20\%) \\
$*$ Registrar & $*$ Coordinators of SCs (100\%) \\
$*$ Professors (03 Nos.) & $*$ Assistant Coordinators (30\%) \\
$*$ Associate Professor (01 No.) & $*$ Academic Counsellors (parent institute) $[26.66 \%]$ \\
$*$ Adsistant Professors (14 Nos.) & $*$ Data entry operator / LDC/UDC (13.33\%) \\
\hline
\end{tabular}

Table 2 revealed that in the main campus of the University, apart from the Vice-chancellor and the Registrar, only three Professors, one Associate Professor, 14 Assistant Professors, and 30 Administrative staffs were working. It was found that most of the faculties were working in adhoc basis. So far no permanent recruitment has been taken place since the establishment of the University. Because of the shortage of the faculty members, the University faces difficulties for developing academic programmes of their own. The University administration was very serious to go for regular appointment of the faculties and other staffs. In the Study Centers, it was observed that the Coordinators of the SCs were discharging their duties as coordinator as well as the in-charge of the programmes. Only in 20 percent of the SCs, there were independent programme coordinators; around 27 percent SCs, counselors had appointed; where as in other SCs, the counseling sessions had clubbed with other SCs.

\section{Status of Academic Programmes, Enrollments, and Pass Out}

\section{Academic Programmes}

The University runs Academic Programmes at various levels like at Certificate, Diploma, P.G. Diploma, Bachelor, Master, and Research level. The status of the programmes are as follows:

Table 3: Academic Programmes at different levels

\begin{tabular}{lll}
\hline Sl. No. & Level of the Academic Programmes & Number(s) \\
\hline 01 & Ph.D. (Arts, Humanities, Science, Commerce, and Education) & $14^{*}$ \\
02 & Master (Social Sciences, Languages, Mathematics) & 10 \\
03 & Bachelor (including BPP and B.Ed.) & 08 \\
04 & PG Diploma & 03 \\
05 & Diploma & 03 \\
05 & Certificate & 08 \\
06 & Proposed & 02 \\
\hline
\end{tabular}

*Ph.D. Programmes are not in offer now. It was offered till 2014. 


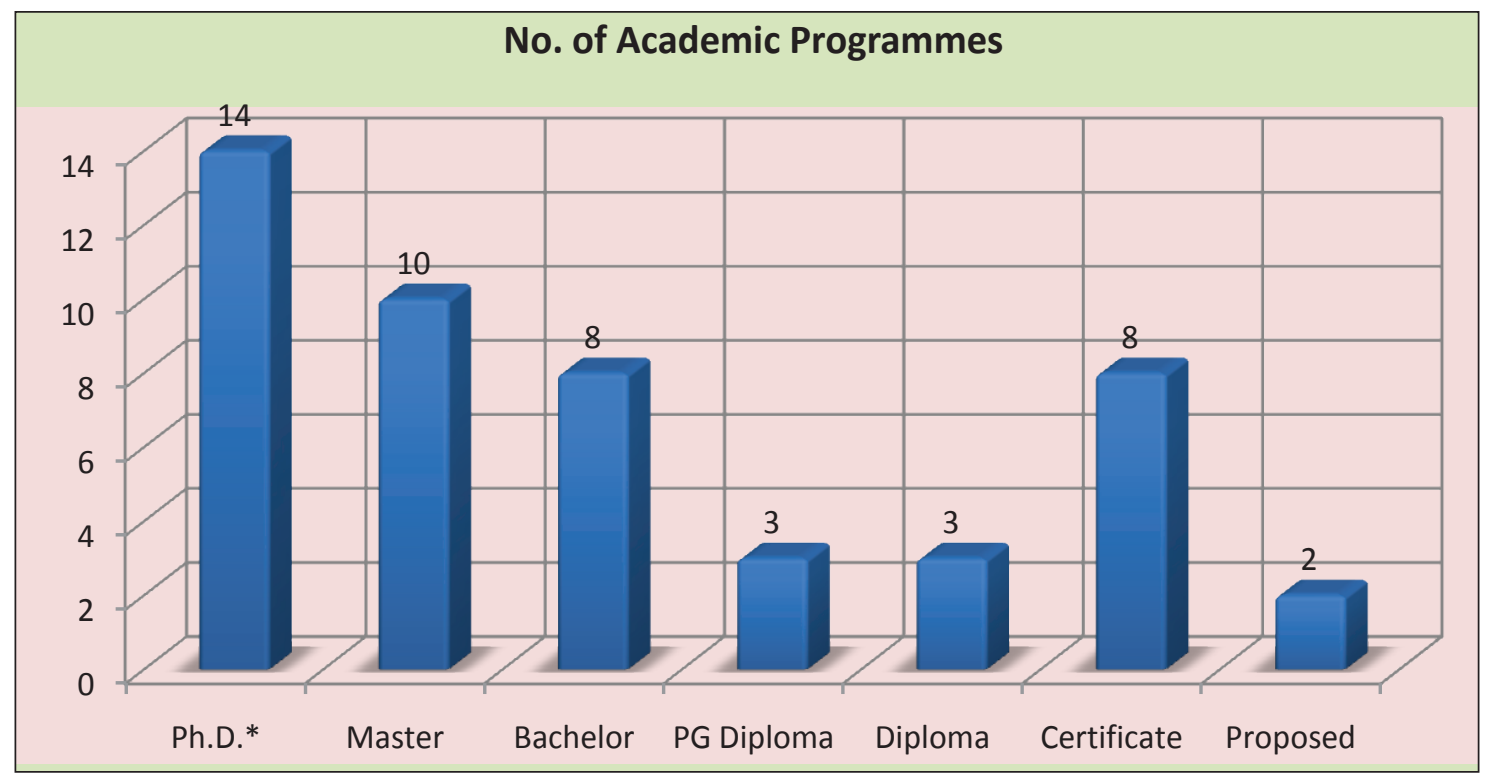

* Ph.D. Programmes are not in offer now. It was offered till 2014.

Fig. 2: Academic Programmes at different levels

Table 3 and Fig. 2 revealed that since the establishment of the University, a total of 46 Academic programmes have launched at different levels. 14 Research Degree programmes had launched by the University which are currently not in offer. The Master, Bachelor, Diploma, PG Diploma, and Certificate programmes launched by the University are respectively 10, 8, 3, 3, and 8. Apart from these, two programmes have proposed to be offered in next Academic Session.

\section{Enrollment and Pass out}

Table 4: Academic Session wise enrollments, appeared, pass out, and pass out percentage of the Learners

\begin{tabular}{llllll}
\hline Session(s) & Enrollment(s) & $\begin{array}{l}\text { Increase / } \\
\text { Decrease in \% }\end{array}$ & $\begin{array}{l}\text { Appeared in } \\
\text { the Exam. }\end{array}$ & Pass out & \% of Pass out \\
\hline $2005-06$ & 3920 & - & $*$ & $*$ & $*$ \\
$2006-07$ & 12723 & 224.56 & $*$ & $*$ & $*$ \\
$2007-08$ & 20034 & 57.45 & $*$ & $*$ & $*$ \\
$2008-09$ & 20516 & 2.40 & $*$ & $*$ & $*$ \\
$2009-10$ & 17433 & -15.02 & $*$ & $*$ & $*$ \\
$2010-11$ & 21880 & 25.50 & $*$ & 6260 & 32.09 \\
$2011-12$ & 13950 & -36.24 & 19502 & 5863 & 48.34 \\
$2012-13$ & 12409 & -11.04 & 12127 & & $*$
\end{tabular}


$\mathcal{P D e y}$

\begin{tabular}{llllll}
$2013-14$ & 21953 & 76.91 & 20253 & 9946 & 49.10 \\
$2014-15$ & 24142 & 9.97 & $*$ & $*$ & $*$ \\
Cumulative & $\mathbf{1 6 8 9 6 0}$ & $\mathbf{5 1 5 . 8 6 \# \#}$ & $\mathbf{5 1 8 8 2} \#$ & $\mathbf{2 2 0 6 9}$ & $\mathbf{4 2 . 5 3 \#}$ \\
\hline
\end{tabular}

*Data are not available; \#Consolidated data of the Academic Sessions 2011-12, 2012-13, and 2013-14; \#\#Decadal growth \% of Enrollments of the Learners.

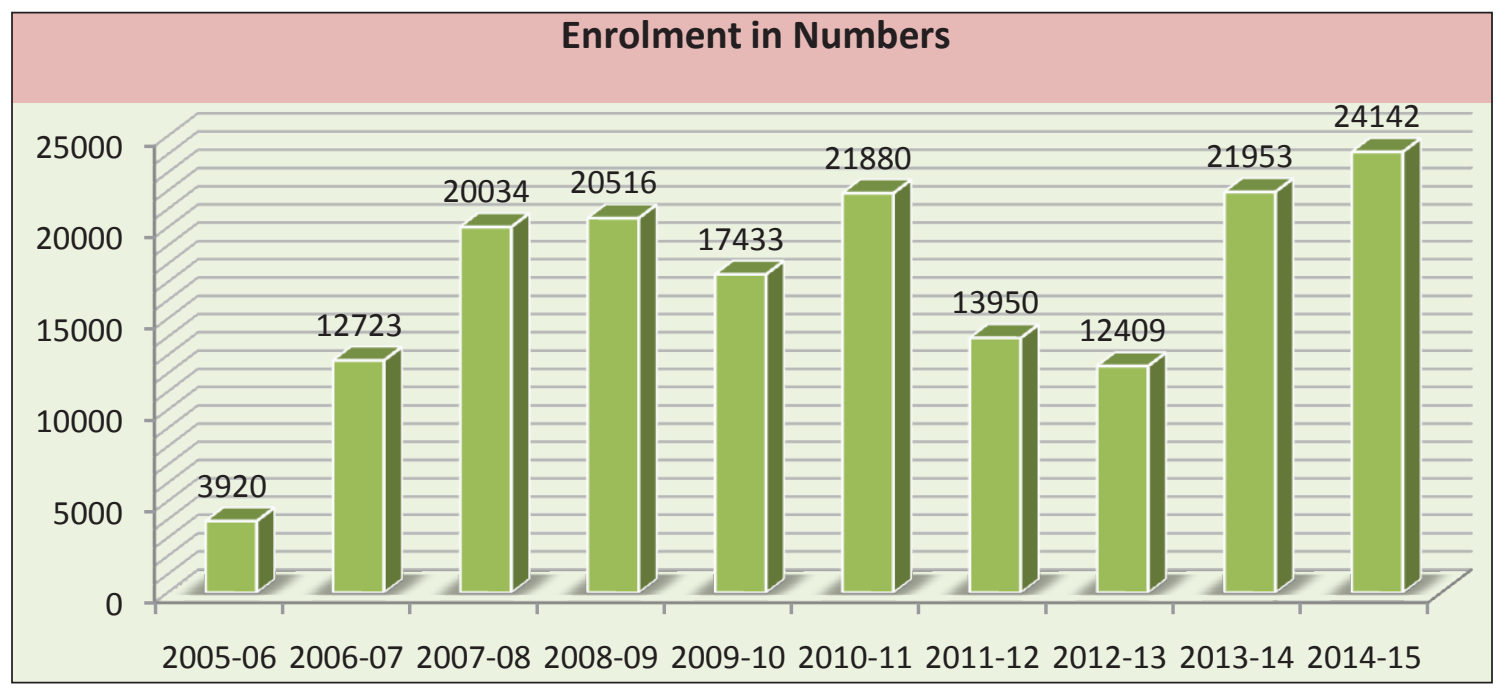

Fig. 3: Year-wise Enrolment of Learners

Table 4 and Figure 3 revealed that, cumulative enrollment of the learners starting from 2005-06 to 2014-15 has reached to 1,68,960 and the decadal growth rate percentage of the enrollment of the learners are 515.86. It was observed that, most of the years there was increase of enrollments of the learners besides the years 2009-10, 2011-12, and 2012-13. Data relating to pass out percentage of the Learners were available for the years 2011-12, 2012-13, and 1013-14. The data revealed that on an average around 43 percent $(42.53 \%)$ of the learners became successful in the Term End Exam in 2011-12, 2012-13, and 2013-14.

\section{Admission Criteria in Different Programmes}

It was observed that the University was following different admission criteria for different programmes. The learners admitted through proper entrance test in most of the professional programmes like B.Ed. and D.Ed. Whereas, in general programmes admission were taking place through the marks/grades they achieved in their last examination as per the eligibility of the programmes. There were limited seats for professional programmes, like B.Ed./D.Ed. NCTE has given permission to them for 500 B.Ed. seats. As per the criteria and norms of NCTE, the University was running the teacher education programmes. 


\section{Development of Academic Programmes and Curriculum Transaction}

\section{Development of Academic Programmes}

As per Table 3, apart from the Ph.D. programmes, the University runs 32 academic programmes at different levels. Out of the 32 academic programmes, the University has developed Self Learning Materials only for six different programmes. For other programmes, they depend upon other institutes like IGNOU. IGNOU has recently stopped supplying SLMs in the programmes they earlier supplied. It creates huge difficulties for them to run their programmes. Still they tried to get it from other State Open Universities in the country. Recently, the University administration has started developing SLMs for all their programmes. For this, they are trying to engage out source agencies like book publishing houses to publish SLMs. They have constituted programme wise committees in the University to develop the curriculum and also to screen the materials developed by out source agencies for final approval.

\section{Curriculum Transaction}

Curriculum transaction is an important aspect in distance education system. For proper transaction of the curriculum, different stages of management mechanism like the University main campus, Regional Centres, and the Study Centres are involved in distance education system. The same system has been in operation for the case of Pt. Sundarlal Shrama Open University. It has Five Regional Centres, and 126 Study Centres established across the State. It was observed that, regular rapport/communication had established among the University main campus, Regional Centres, and the Study Centres. The Vice-chancellor as well as the Directors of the Regional Centres had regularly visited the Study Centres for supervising the works carried out at the level of SCs. Time and again the University has conducted orientation programmes for the academic counselors, programme in-charges, as well as the coordinators of the study centres. Still, many difficulties were observed to appointing the counselors, conducting the counseling as well as the workshops sessions, and providing technology based support system to the counselors and the learners.

It was observed that around 23 percent Study Centres had counselors of their own, but most of the Study Centres were running without counselors. It was clarified that the Learners those have enrolled in a SC where counselors are not apointed were send to other SCs for attending the counseling. Mostly, by clubbing 4/5 SCs, they conducted counseling. Around 51 percent learners reported that they have not received any counseling during their studies. It was observed that regular counseling, practical as well as workshop had conducted for professional programmes like B.Ed., D.Ed., D.C.A., and P.G.D.C.A., but in average cases in general programmes, regular counseling was not organized.

Teleconferencing, Interactive Radio Counselling, and Audio-video materials support to the learners are the important aspect in transacting curriculum in distance education system. In this regard, it was observed that the learners were not getting any such technological support from the University. During interaction with the Vice-chancellor, this issue was also raised. The Vice-chancellor assured to work on in this and to develop the audio-video programmes on various themes and supply to the learners. 
P Dey

It was observed that the University really needs proper orientation from the ICT and technical experts for developing audio-video programmes.

Evaluation is also a crucial aspect in transaction of curriculum in distance education. The University follows Term End as well as Continuous Assessment for awarding the learners. For this, they adopt Assignments, Practical, Projects, and Term End Theory Exam. It was also observed that both internal as well as external examination system were adopting for evaluating the performance of the learners.

\section{Support Services Received and Difficulties Faced by the Academic Counsellors and the Learners}

\section{Academic Counsellors}

Table 5: Support services received and difficulties faced by the Counselors

\begin{tabular}{lll}
\hline Sl. No. & Particulars & \% of ACs \\
\hline 01 & Not received any kind of Orientation from the University & 86 \\
02 & Received support from the SCs & 78 \\
03 & Reading SLMs before taking counseling sessions & 53 \\
04 & Following references and suggested readings with SLMs & 47 \\
05 & Using lecture and discussion methods in counseling & 100 \\
06 & Difficulties to finish the course as per the schedule & 57 \\
07 & Difficulties face to understand the SLMs & 61 \\
08 & Not facing difficulties to discharge duties for in face-to-face teaching as well as for & 92 \\
& Open University & 6 \\
\hline
\end{tabular}

A total of 51 (Male-26, Female-25) Academic Counsellors had interviewed in the study. Among them, 86 percent academic counselors reported that they have not received any kind of orientation from the University for delivering the programmes. They also reported that they face difficulties to discharge their duties in counseling sessions. They usually conduct it as they teach in face-to-face teaching and also they face difficulties to understand the curriculum of the programmes and the SLMs (61\%). 78 percent academic counselors reported that the Study Centers were providing necessary supports like providing SLMs of the courses, and ICT facilities for conducting counseling. All most all the counselors reported that they use lecture and discussion methods to conduct counseling. Around 53 percent counselors reported that they read SLMs before taking the counseling, where as 47 percent counselors reported that they follow references and suggested readings given in the Units with the SLMs. 57 percent counselors reported that they are unable to complete the course within the counseling schedule they received. 92 percent counselors reported that they did not face difficulties or over loaded in discharging their duties both in face-to-face teaching as well as for the Open University. 


\section{Learners:}

Table 6: Support services received and difficulties faced by the Learners

\begin{tabular}{lll}
\hline Sl. No. & Particulars & \% of Learners \\
\hline 01 & Received pre-admission counseling & 73 \\
02 & Received SLMs & 98 \\
03 & Received counseling schedule from the SCs & 67 \\
04 & Medium of counseling was matching with the medium they opt in their programme. & 78 \\
05 & Receiving assignment questions in time. & 99 \\
06 & Receiving back evaluated assignment with comments. & 20 \\
07 & Dissatisfied with assignment grades & 52 \\
08 & Dissatisfied with TEE grades & 53 \\
09 & Satisfied with the services provided by the University & 61 \\
10 & SCs were supportive for the learners & 45 \\
11 & Satisfied with the academic facilities provided by SCs & 16 \\
12 & Satisfied with the administrative support & 16 \\
13 & Satisfied with ICT support & 25 \\
14 & Satisfied with hands-on activities/practical & 32 \\
15 & Satisfied with the counseling and other contact sessions & 34 \\
16 & Satisfied with the communications & 58 \\
17 & Difficulties face to get certificates from the University & 6 \\
\hline
\end{tabular}

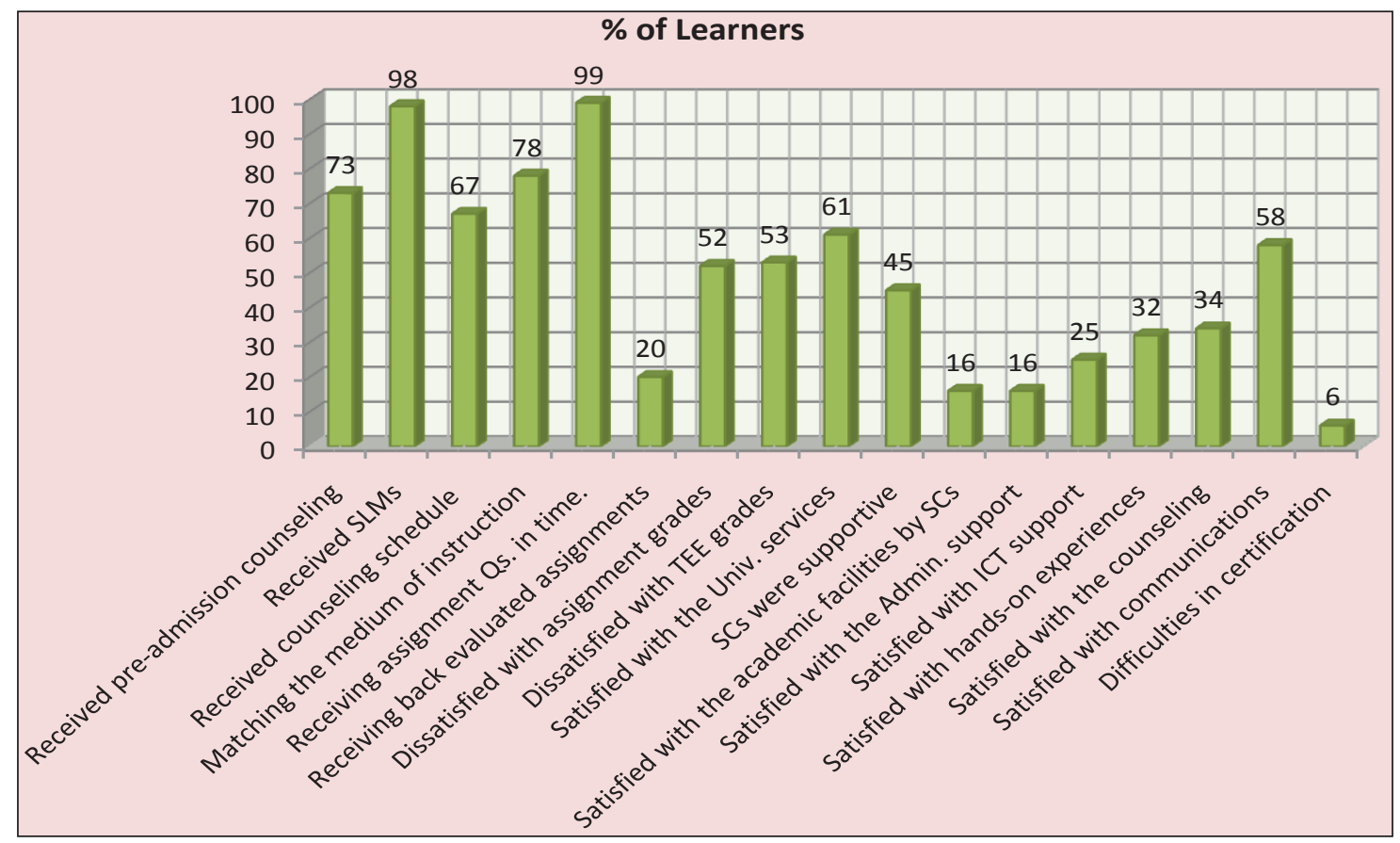

Fig. 4: Support services received by the Learners 
P Dey

Table 6 and Fig. 4 revealed that in more than 50 percent of the cases the learners received pre-admission counseling, SLMs, schedule of counseling, and assignment Questions. They were dissatisfied with assignment and TEE grades ( $52 \& 53 \%$ ); satisfied with the communications received by the University (58\%); and happy with the medium of counselling (87\%). On the contrary, in less than 50 percent of cases the learners received back their assignments with the comments made by the evaluators; satisfied with academic, administrative, ICT support, hands-on activities, counseling, and other supports provided by the SCs. The analysis shows that the support services to the learners need to be strengthened both at the University as well as at the SC level.

\section{Research Degree Programmes}

The University offered Ph.D. in 14 different subjects of the disciplines of Arts and Humanities, Languages, Commerce, Science, and Education. Mostly the supervisors appointed for guiding research were from the other institutes as because lack of faculties in the University. The Research Degree programmes have been stopped by the University from 2014 onwards as because of the guidelines and norms of UGC. The enrolled Ph.D. scholars were getting course work and other research related supports from the University.

\section{Cost and Benefits of the University}

The cost and benefits of the University has been analysed in last five years. Table 7 provides a clear picture of earning and expenditure sources of the revenues of the University.

Table 7: Year-wise cost benefits analysis of the University (Figures are in Lakhs)

\begin{tabular}{|c|c|c|c|c|c|c|c|c|c|}
\hline \multirow[b]{2}{*}{ Sl. No. } & \multirow[b]{2}{*}{$\begin{array}{l}\text { Financial } \\
\text { Year }\end{array}$} & \multicolumn{4}{|c|}{ Heads of Earning Sources } & \multirow[b]{2}{*}{$\begin{array}{l}\text { Total } \\
\text { Earning }\end{array}$} & \multirow[b]{2}{*}{ Expenditure } & \multirow[b]{2}{*}{ Balance } & \multirow[b]{2}{*}{$\begin{array}{l}\% \text { of } \\
\text { Saving }\end{array}$} \\
\hline & & 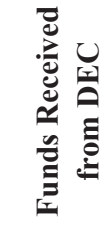 & 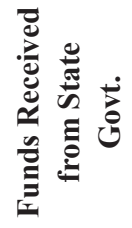 & 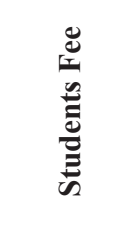 & 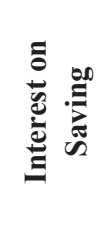 & & & & \\
\hline 1 & 2010-11 & 152 & 223.18 & 545.37 & 9.61 & 930.16 & 567.82 & 362.34 & 38.95 \\
\hline 2 & 2011-12 & 99.16 & 357.40 & 1153.36 & 87.64 & 1697.56 & 661.44 & 1036.12 & 61.03 \\
\hline 3 & $2012-13$ & 250 & - & 922.50 & 38.89 & 1211.39 & 856.59 & 354.80 & 29.28 \\
\hline 4 & 2013-14 & 300 & 160 & 1684.01 & 36.03 & 2180.04 & 924.09 & 1255.95 & 57.61 \\
\hline \multirow[t]{2}{*}{5} & 2014-15 & - & 160 & 1586.95 & 40.99 & 1787.94 & 1196.16 & 591.78 & 33.09 \\
\hline & Total & 801.16 & 900.58 & 5892.19 & 213.16 & 7807.09 & 4206.1 & 3600.99 & 46.12 \\
\hline
\end{tabular}




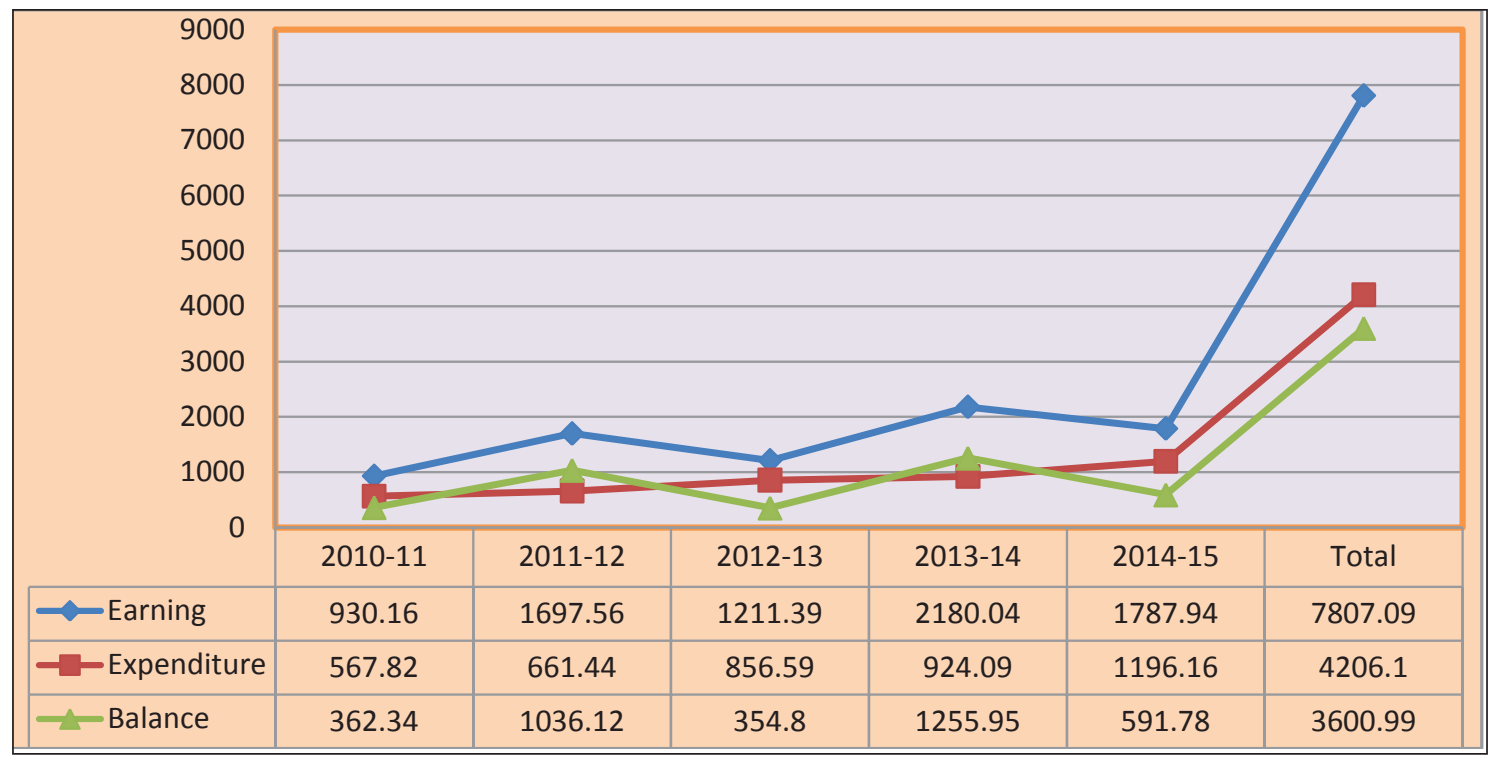

Fig. 5: Year-wise earning, expenditure, and balance of the University (Figures are in Lakhs)

Table 7 and Fig. 5 revealed that the main sources of income of the University in last five financial years (2010-11 to 2014-15) were funds received from Distance Education Council (801.16 Lakhs); funds received from State Government (900.58 Lakhs); revenues from Students fee (5892.19 Lakhs); and interest on savings (213.16 Lakhs). In last five financial years, it was observed that the Total Income of the University was 7807.09 Lakhs, whereas the Total expenditure was 4206.1 Lakhs. The University is presently having a balance amount of 3600.99 Lakhs. Financial year-wise analysis shows that in every financial year, the University managed to get considerable balance benefit in comparison to the expenditure they incurred.

\section{RESULTS AND DISCUSSION}

The evaluation study of the Open University has conducted keeping in view exploring the over all functioning of the University. The major aspects of the study was to explore the status of material and human resources available in the main campus as well as the study centres of the University; status of academic programmes, enrollments, and pass outs; development of academic programmes and its transaction; admission criteria in general as well as professional programmes; status of research degree programmes; support services and difficulties faced by the counselors as well as the learners; and cost benefit aspect of the University. The results in different sections of the study are as follows:

\section{Availability of Facilities (Material and Human Resources):}

University Main Campus: University main campus has established in 75 Acers of land in the outer 
area of City Bilaspur. The campus is full of flora and fauna, beautiful greeneries with boundary walls. Construction of first wing of the University has been completed where the University is presently functioning. The second wing of the University is under construction in the campus. The University has well equipped office of the Vice-chancellor; meeting and conference rooms; different sections for administration of the University; academic departments; independent rooms for the faculty members; material production and storage section; general and departmental libraries; and buses \& small vehicles. Apart from these the University has five RCs and 126 SCs. It was observed that all most all the infrastructures in the University were in well condition for use. The main shortcomings in regards to infrastructures in the main campus are: they do not have a media centre/lab; science lab; radio centre; and audio-visual rooms which is essential for the part of an institute of distance learning.

Besides the material resources, the University suffers huge shortage of human resources. It was observed that only three professors, one associate professor, 14 assistant professors, and 30 administrative staffs had appointed in the University that is also in adhoc basis. The University administration was very much serious to appoint the faculties for smooth functioning of the University. The Vice-chancellor reported that the process of recruitment has been started and it may take few months to complete the process.

Study Centres: In more than 70 percent of the cases the SCs do not have an independent wing for functioning; rooms for programme in-charges; counseling rooms, meeting rooms; library; laboratory; audio-visual rooms; TV/LCD; radio, computer, internet facility, LCD projector; etc. where as in 70 percent of the cases the SCs had independent coordinator rooms as well as the toilet facilities for the Boys/Girls.

The availability of human resources in the SCs shows that all the SCs had coordinator; only in 20 percent SCs had programme in-charges; less than 30 percent SCs had counselors, data entry operators/ LDCs/UDCs. Most of the counseling sessions had clubbed with SCs.

\section{Academic Programmes, Enrollments, and Pass Out}

Currently the University offers 32 Academic Programmes at various levels. Before 2014, the University was offering $14 \mathrm{Ph} . D$. programme in different subjects of the disciplines of Humanities, Arts, Sciences, Commerce, and Education. Now it has stopped as per the norms of the UGC. The University has also proposed two programmes for launching in the next academic session. Since 2005-06 to 2014-15, the University has managed to get a cumulative enrollment of 1,68,960. It has observed that every year there was increase in enrollments of the learners. The decadal growth of enrollment percentages of the learners was 515.86. The available average pass out percentage data in the sessions 2011-12, 2012-13, and 2013-14 were 42.53. The result shows that the growth of academic programmes, enrollments and pass out percentage of the learners were satisfactory.

\section{Admission Criteria in Different Programmes}

The data shows that for admission in professional programmes like B.Ed., D.Ed. and others, the University 
was conducting entrance test as per the norms of the regulatory bodies, where as for admission in various general programmes the University had their own admission norms. The seats for professional programmes had limited by the regulatory bodies.

\section{Research Degree Programmes}

The University had been offering Ph.D. programmes in 14 different subjects of the disciplines of Arts, Humanities, Commerce, Sciences, and Education. The admission was on the basis of availability of supervisors as well as the presentation of the research proposal. It was observed that in most of the cases the supervisors were from other Universities/Institutes. The Course work has been offered to the scholars. Presently, the University has stopped all the Ph.D. programmes as because the new norms of the UGC.

\section{Development of Academic Programmes and Curriculum Transaction}

Currently the University offers 32 Academic Programmes at Certificate, Diploma, PG Diploma, Bachelor, and Master degree level. Among the 32 programmes, the University has developed SLMs only for six different programmes. For other programmes, they manage to get the SLMs from other Universities like IGNOU. In a decision, IGNOU has stopped supplying SLMs to them. In this regard, they face huge difficulties to provide materials to the learners. The University has recently started developing materials of their own. For this they consulted publishing houses those can develop materials for them. The University has formed programe wise committees those will develop curriculum for the programme and the publishing houses will develop materials as per the curriculum. The materials will be scrutinized by the committee members before making it final. The University is doing this exercise as because shortage of academic staffs in all most all the disciplines.

The University has developed a three tire system : the main campus of the University, Regional Centres, and the Study Centres for transacting the academic curriculums. The University has five RCs and 126 SCs. It was observed that Academic Counsellors were not appointed in most of the SCs. They had developed a system of clubbing the SCs for conducting the counseling. The treatments for transacting curriculum for professional programmes were different. The practical as well as the workshops had regularly conducted for professional programmes. The general programmes were suffering a lot. Use of technology for transacting academic programs was the weakest part for the University. The learners did not get any type of technological support like teleconferencing, interactive radio counseling, audiovideo materials for their studies. The University management assured to go for immediate developing of audio-video materials. For this they require a thorough orientation for developing the materials.

Most of the programmes had theory as well as practical components. In theory, the evaluation was based on Term End Examination as well as the Continuous Assessment through assignments. Evaluation was done on the basis of the performance of the learners in TEE and the assignments. Both internal and external examination systems were prevailed to certify the learners. 


\section{Support Services Received and Difficulties Faced by the Academic Counsellors and the Learners}

Most of the counselors reported that they have not received any kind of orientation from the University. They also faced difficulties in completing the courses they had assigned. Some time they failed to understand the SLMs and faced difficulties to transact it. Because of lack of orientation, they simply teach the learners like face-to-face teaching in lecture or discussion method. In most of the cases they were getting supports from the SCs like SLMs, and other materials for taking the counseling sessions. More than 50 percent of academic counselors were conducting counseling by reading the SLMs, and in some cases they prefer to refer the references and the suggested readings. Most of the counselors reported that they were not getting any difficulties for discharging duties both in face-face-face teaching as well as for the Open University.

In most of the parameters, the support services received by the learners were not satisfactory. More than 50 percent of the learners were not satisfied with the counseling; hands-on experiences received from the SCs; ICT based support; other administrative support; academic facilities provided by the SCs; dissatisfied with TEE and assignment grades; audio-video materials and technology based interaction support; and getting back evaluated assignments with comments. On the contrary most of the learners were satisfied with pre-admission counseling; SLMs; getting schedule of counseling and assignment questions; medium of instruction in counseling; and the services and communication received from the University. Over all, it may be said that the support services received by the learners need to be improved.

\section{Cost Benefit aspect of the University}

It was studied that the University is in a comfortable position to manage its finance. In last five years (since 2010-11 to 2014-15), after managing all its expenditure, the University has managed to save a balance revenue of 3600.99 Lakhs (46\%). It was observed that over the years there was average percentage of balance amount of revenue was $44 \%$. The year wise variation of percentage of balance amount was 29 to 61 percent.

\section{Suggestions and Implications}

The following suggestions and implications may be put forth for better functioning of the University:

In general, it was realized that the University needs a thorough understanding of the concept of distance learning; its philosophy; theories and models of development of materials (print and electronic); its organization; functioning at different levels; support to the learners; etc. For this, a large scale interaction is needed with the established system of distance learning like IGNOU.

The University needs to have a media production centre at the main campus and low frequency radio centres at the main campus as well as its regional centres for providing better academic supports to the learners. Large scale audio-video materials need to be developed for the learners. 
In priority basis, permanent faculty appointment needs to be done so that the regular services of the University as well as the work of development of academic programmes would be carried out. Regular orientation programmes for the programme coordinators, faculty members, programmein-charges, academic counselors, study centre coordinators, and for the ICT staffs need to be organized by the experts at different fields for making them aware about the process of developing programmes, developing SLMs, audio-video materials, taking counseling and workshop sessions, and also for performing the work of evaluation.

The university should try to develop SLMs of their own without giving this task to the Publishing Houses. The faculty members of the University should be involved in developing materials for different programmes. In this regard, the University should try to get expert advice and exposure from the established Universities like IGNOU.

The SCs need to be more empowered with materials as well as human resources for providing all types of support to the learners. Study Centre should not be established in non-education institutes like Panchayat, or in Tahasil Office. All SCs should be of adequate academic counselors for the programmes offered by the SCs.

Regular counseling sessions both for general as well as professional programmes need to be conducted in the SCs. The counselors need to understand the methods of taking the counseling sessions, evaluate the assignments, and also the Term End Examination.

Regular monitoring and supervision to the SCs by the Vice-cancellor of the University, University faculties, and officers from the RCs need to be done for keeping an eye on the SCs in their activities.

Regular feedbacks by the learners as well as by the academic counselors need to be taken and accordingly the system should be strengthened.

Though the decadal growth in learners enrollment and revenue has increased significantly, its other aspect of providing quality education should not be neglected. A definite portion of revenue needs to be spent for providing better academic and other support to the learners.

The interest of the Vice-chancellor to incorporate skill-based components in each and every academic programme is definitely a welcoming step for making the learner empower in the required skills which they like for.

Ultimately, care should be taken to 'reach the unreached' which is the slogan of distance education system and the social responsibility of the University should be realized. 
N Dey

\section{REFERENCES}

1. Anand, S. 1979. University Without Walls: Correspondence Education in India. Vikas Publishing House. New Delhi.

2. Balasubramaniam, S. 1986. The status of correspondence courses in India. New Delhi: University News, 24(42).

3. Biswal, B.N. 1979. A Study of Correspondence Education in India. Ph.D. Education, The Maharaja Sayajirao University of Baroda.

4. Dass, B.C. and Dass, S. 2001. Viewing Doordarshan (TV) programmes, preferences of high school students. Indian Journal of Open Learning, 10(1): 100-109.

5. Datt, R. 1984. Planning and Development of Distance Education. Journal of Higher Education, 9(8).

6. Datt, R. 1988. Distance Education in A.D. 2000. Journal of Educational Planning and Administration, 2(3\&4).

7. Daugherty, M. and Funke, B.L. 1998. University Faculty and Student Perceptions of web-based Instruction. Journal of Distance Education, 13(1): 21-39.

8. Khan, I. 1982. Suitability of Teaching English through Correspondence Courses as Offered by some Indian Universities at the first Degree Level. Ph.D. Education, Utkal University.

9. Koul, L. 2006. Research on Indian Distance Education. Four Decades of Distance Education in India - Reflection on Policy and Practice (ed.). Viva Books Private Limited, New Delhi: India. Murgatroyd, S. (1980). What actually happens in Tutorials? Teaching at a distance, 18(Winter): 44-53.

10. Nagaraju, C.S. 1982. Evaluation of Correspondence-cum-contact In-service teachers training pragramme in Kerala. Institute of Social and Economic Change, Bangalore. (Ministry of Education, Government of India financed project).

11. Pajo, K. and Wallace, C. 2001. Barriers to the Uptake of web based Technology by University Teachers. Journal of Distance Education, 16(1): 70-84.

12. Panda, S. and Garg, S. 2003. Distance Learning in India with Open Schools. In: Bradley, J. (ed.), the Open Classroom: Distance in and out of School. London: RoutledgeFalmer.

13. Prasad, V.S. 1987. APOU Learner Profile: A Case Study. In B.N. Koul et al. (eds.). Studies in Distance Education. New Delhi: AIU and IGNOU.*

14. Sahoo, P.K. 1985. A Study of Correspondence Education in and Indian University. Ph.D. Education, The Maharaja Sayajirao University of Baroda.

15. Sahoo, P.K. and Mucchal, M.K. 2001. Effectiveness of Video instruction strategies in general science and social science at secondary stage of national open school. OSAC Journal of Open Schooling, 2(1): 58-73.

16. Singh, B. et al. 1994. Correspondence/Distance Education in India: An in-depth study covering the year 1989-90. New Delhi: IGNPU.

17. Venkaiah, V. 2005. Educational Media in Dr. B.R. Ambedkar Open University with special reference to Teleconference, in Usha V. Reddi and Sanjaya Mishra (eds). Educational Media in Asia, Commonwealth of Learning. 